Irena Jaros

Uniwersytet Łódzki

Katedra Dialektologii Polskiej i Logopedii

\title{
O PRZYDATNOŚCI MIKROTOPONIMÓW DO BADAŃ SLOWOTWÓRSTWA GWAROWEGO (na przykładzie terenowych nazw przymiotnikowych)
}

Od dawna wiadomo, że obie dziedziny językoznawstwa: onomastyka i dialektologia, mogą się wzajemnie wspomagać i uzupełniać zarówno w zakresie analizy faktów językowych, jak i metodologii badań [zob. np. Taszycki, 1963; Zaręba, 1968; Rzetelska-Feleszko, 1986; Gala, 1986; 2001; Rospond, 1986; Cieślikowa, 2003; Pelcowa, 2007]. O stosunku tych dwu dziedzin Ewa Rzetelska-Feleszko tak pisała w roku 1986:

Precyzując (...) wzajemny stosunek tych dwu działów stwierdzić można, że o ile dialektologia zajmuje się przedstawianiem całości systemu językowego (dialektów), to onomastyka bada jedynie pewną jego część, tj. nazwy własne. Nazwy zaś należą w zasadzie do jednej z płaszczyzn języka - płaszczyzny leksykalnej, aczkolwiek mogą też one stanowić ilustrację procesów fonetycznych, słowotwórczych czy fleksyjnych [Rzetelska-Feleszko, 1986, s. 69].

Na temat przydatności danych onomastycznych do badań słowotwórstwa gwarowego wypowiadał się prof. Sławomir Gala [2001, 2003], który m.in. zwrócił uwagę na ważną rolę badań toponimów, w tym nazw obiektów niezamieszkałych, np. pól, łąk, pastwisk, lasów, pagórków itp. [2003, s. 61]. Ta wypowiedź stała się inspiracją do ponownego podjęcia tematu, przyjrzenia się pewnym faktom językowym, ukrytym w mikrotoponimach, które mogą uzupełnić naszą wiedzę na temat zróżnicowania słowotwórczego polskiego obszaru dialektalnego. Nazwy terenowe, powstałe i funkcjonujące w obrębie mikrowspólnot lokalnych, z uwagi na ich genezę i nieoficjalny charakter, są elementem gwary [Śmiech, 1983, s. 37], przechowują leksykę i właściwości językowe należące do różnych warstw chronologicznych, podobnie jak regionalne odmiany języka [zob. Mrózek, 2014, s. 27]. 
Ścisły związek z apelatywami na etapie ich kreacji widoczny jest w strukturze, zarówno w odniesieniu do podstaw słowotwórczych ${ }^{1}$, jak i formantów. Analiza mikrotoponimów umożliwia odkrycie charakterystycznych dla danego terenu cech morfologicznych, co może być przydatne w geografii lingwistycznej, oraz wydobycie dawniejszych, archaicznych struktur i znaczeń apelatywów, które aktualnie w gwarach występują śladowo lub nie występują w ogóle.

Przedmiotem moich rozważań uczynię kilka zjawisk mieszczących się w zakresie słowotwórstwa przymiotników funkcjonujących w gwarach, posługując się, jako materiałem ilustrującym, mikrotoponimami wyekscerpowanymi z opublikowanej, niedokończonej pracy Witolda Śmiecha Przymiotnikowe nazwy terenowe Polski [1996]. Ich wybór podyktowany został chęcią ukazania możliwości wykorzystania danych onomastycznych do badań słowotwórstwa apelatywnego w gwarach. Swoją uwagę skupię przede wszystkim na przymiotnikowych dubletach słowotwórczych, czyli formacjach utworzonych od tych samych podstaw za pomocą różnych pod względem budowy morfologicznej formantów, które wnoszą do nich te same znaczenia oraz derywatach kontynuujących stan staropolski. Zjawisko wariantywności słowotwórczej w zakresie przymiotników pospolitych charakteryzuje zarówno gwary, jak i polszczyznę ogólną ${ }^{2}$. Znane było także w staropolszczyźnie, o czym przekonują licznie występujące w niej dublety słowotwórcze [zob. Kleszczowa, 2003], poświadczające rywalizację poszczególnych typów słowotwórczych. Ich występowanie w strukturze nazw własnych, zlokalizowanych geograficznie, może posłużyć weryfikacji danych o zasięgach terenowych poszczególnych sufiksów apelatywnych i/lub ukazać zmiany w zakresie ich funkcji semantycznej. Nie jest moim celem pełne opracowanie zagadnienia, jedynie próba pokazania, w jaki sposób mikrotoponimy, szczególnie nazwy terenów niezamieszkanych (anojkonimy), odzwierciedlające charakterystyczne dla gwar polskich cechy morfologiczne przymiotników, mogą pomóc w badaniach nad słowotwórstwem gwarowym. W sytuacji niedostatków naszej wiedzy na temat zróżnicowania słowotwórczego terenowych nazw własnych [zob. Mrózek, 1998, s. 250] oraz gwarowych derywatów apelatywnych, całkowite opracowanie tematu, przynajmniej na tym etapie badań, wydaje się zadaniem niewykonalnym.

1 Zob. np. nazwy przymiotnikowe Glapi Dót i Wroni Dół [Śmiech, 1996, s. 17, 24], utworzone od regionalnych wariantów leksykalnych: glapa i wrona 'Corvus, corone cornics'.

2 Por. np. przymiotny i przymiotnikowy, jabłkowy i jabłeczny, szklarniany i szklarniowy, wystawowy i wystawienniczy niezróżnicowane znaczeniowo [GWJP, s. 499; Satkiewicz, 1987, s. 340-382] oraz np. dziecięcy i dziecinny, których aktualny zakres użycia uwarunkowany jest kontekstowo. 
Prymarny charakter nazwy pospolitej wobec nazwy własnej implikuje sposób tworzenia toponimów, zarówno pod względem wspólnej funkcji semantycznej formantów ${ }^{3}$, jak i w pewnym zakresie technik derywacyjnych [Gala, 2003, s. 58]. W obszernym materiale zamieszczonym w pracy W. Śmiecha [1996] odnajdujemy przymiotnikowe nazwy terenowe, należące do trzech podstawowych typów. Są to: 1) nazwy wielowyrazowe, stanowiące zestawienia przymiotnika z rzeczownikiem, jako członem utożsamiającym, np. Skośna Droga, -ej (nz. drogi), lub konstrukcje z przyimkiem, np. Pod Lipia Góra (nz. pola); 2) nazwy eliptyczne, będące rezultatem uproszczenia nazw wieloskładnikowych, powstałe po usunięciu rzeczownika, np. Bucza, -ej (nz. pola), Jamne, -ego (nz. pola), niekiedy włączone do konstrukcji przyimkowych, np. Pod Skalitem (nz. pola); 3) eliptyczne zestawienia adiektywne, np. Krajnie Lisie (nz. łąki, lasu). Już pobieżny przegląd zamieszczonego w pracy materiału pokazuje, że postaci przymiotników pospolitych, włączone bez zmian do mikrotoponimów, posiadają znamiona gwarowości, charakteryzują się wykładnikami formalnymi zróżnicowanymi geograficznie, w wielu wypadkach poświadczają stan historyczny.

Gwary polskie charakteryzuje dialektalne zróżnicowanie formantów przymiotnikowych -aty//-asty oraz -ity//-isty, uważane za innowację prasłowiańską. Sufiks -aty upowszechnił się w dialektach łużyckich i czeskich oraz przyległych do nich śląskich i wielkopolskich [Winkler-Leszczyńska, 1964, s. 66; Dejna 1994, mp. 69], występując tam niemal konsekwentnie w przymiotnikach charakterystycznych, tworzonych przede wszystkim od rzeczowników, np. gliniaty, kolczaty, liściaty. Na pozostałym obszarze Polski, pojawiają się obok siebie zarówno formacje z -aty, jak i z -asty, np. gliniaty i gliniasty, liściaty i liściasty. Postać przyrostka -ity ma zasięg szerszy, bowiem w gwarach Polski zachodniej, po linię: Jabłonków - Cieszyn - Katowice - Częstochowa - Łowicz - Płock - Rypin-Brodnica - Świecie - Chodzież przeważają lub występują obocznie do -isty przymiotniki typu wodnity, piaszczyty [Dejna, 1993, s. 201]. Sufiks -ity występuje także na Kaszubach oraz wyspowo w Małopolsce [zob. MAGP, mp. 505].

Wśród mikrotoponimów o motywacji topograficznej, charakteryzującej, odnajdziemy wiele nazw przymiotnikowych z sufiksami -aty i -asty, poświadczających ich zróżnicowanie w wymiarze morfologicznym oraz geograficznym [por. Gajda, 1987]. Zostały one utworzone głównie od nazw roślin i wskazujących na właściwości terenu, np. Chojnate Bagno (nz. bagna, Lipno4) i Chojnasta Góra

Zob. np. dzierżawczy charakter toponimów z formantami -ów, -in, -sk(i).

4 Lokalizację przykładów, ograniczoną do nazwy siedziby powiatu wg podziału sprzed $1974 \mathrm{r}$. lub nazwy regionu ustalonego na podstawie wykorzystanych źródeł, podaję wg danych zamieszczonych w pracy W. Śmiecha [1996]. 
(nz. lasu, Biłgoraj), Gliniata Góra (nz. góry i pola, Kościerzyna) i Gliniasta Góra (nz. wzgórza, Lipno; nz. góry, Kościerzyna, Sejny, Augustów, Suwałki), Keppiate Bagno (nz. bagna, Golub-Dobrzyń, Lipno) i Kepiaste Bagno (nz. bagna, Lipno, Suwałki), Kepiate Stajanie (nz. pola, Nowy Targ) i Kepiaste Stajanie (nz. pola, Nowy Targ), Małe Torfiate, Wielkie Torfiate (nz. stawów, Tuchola) i Torfiaste Łąki (nz. łąki, Puławy), Torfiaste (nz. łąk, Radzyń). Na uwagę zasługują nazwy pochodzące $\mathrm{z}$ terenów położonych bądź na granicy zasięgów konsekwentnego występowania formacji apelatywnych z -aty, bądź na obszarze funkcjonowania obu ich postaci: z -aty i z -asty, np. dawnego powiatu lipnowskiego oraz nowotarskiego, gdzie zanotowano obocznie występujące przymiotnikowe mikrotoponimy, np. Kepiate // Kepiaste Bagno, Kępiate // Kępiaste Stajanie, nawet w obrębie jednej wsi, np. Skrzydlate // Skrzydlaste Stajanie (nz. pola, Zubrzyca Dolna, Nowy Targ).

Nazwy zestawione z określającym członem przymiotnikowym $\mathrm{z}$ formantem -ity lub ich postaci eliptyczne nie są zbyt licznie egzemplifikowane w pracy W. Śmiecha, w odróżnieniu od formacji z suf. -isty, które przeważają liczebnie [zob. 1996, s. 130-133]. W zaprezentowanym materiale odnajdujemy jedynie dwa przykłady dubletów słowotwórczych, np. Jemielity Ług (nz. bagna, Biała; nz, stawu, nieużytku, Janów Lubelski) i Jemielisty Las (nz. lasu, Łomża); Skalite, -ego (nz. góry, Bielsko-Biała) i Skaliste, -ego (nz. pola, Nowy Targ; nz. lasu i góry, Wadowice).

Podobnie jak w przypadku apelatywów, wśród których pojawiają się przymiotniki utworzone od tych samych podstaw za pomocą przyrostka -aty//-asty lub -ity//-isty, np. kamieniaste i kamieniste pole, mulaste i muliste dno [zob. np. Jaros, 2001, s. 105, 106] wśród nazw terenowych występują nazwy, np.: Bagniasty, -ego (nz. stawu, Chojnice) - Bagniste, -ych (nz. łąki, Chodzież), Bagniste Łąki (nz. łąk, Radziejów); Kępiaste Bagno (nz. bagna, Lipno, Suwałki), Bagno Kepiaste (nz. bagna, Biała Podlaska) - Kępiste Błoto (nz. stawu, Tuchola, Wołomin; nz. lasów, Dwor Mazowiecki; nz. łąki, Włoszczowa, Zwoleń); Piaszczata, -ej (nz. lasu, m. w lesie, Włocławek), Piaszczate, -ego (nz. lasku, Bielsk Podlaski) - Piaszczysta, -ej (nz. góry, Jędrzejów), Piaszczyste, -ego (nz. góry, Jędrzejów), Piaszczyste, -ych (nz. góry, Kartuzy; nz. pola, Siedlce), Piaszczysty, -ego (nz. dołu, Kartuzy). Ta wariancja potwierdza małą stabilność obu sufiksów, które mogły w gwarach wchodzić w relacje słowotwórczo-semantyczne z tymi samymi podstawami.

Do cech słowotwórstwa gwarowego należy inna - niż w języku ogólnopol-

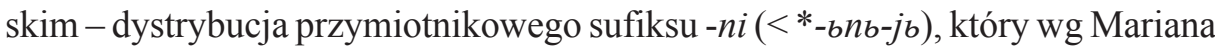
Kucały tworzył w przeszłości przymiotniki oznaczające położenie w przestrzeni 
oraz czasie i przed wiekiem XVI został wyparty, z nielicznymi wyjątkami, przez bliski brzmieniowo przyrostek -ny [Kucała, 1955, s. 13-15; zob. Kleszczowa, 2003, s. 33]. W gwarach Mazowsza, Śląska, a zwłaszcza Małopolski formacje z przyrostkiem -ni zachowały dłużej swoją produktywność, czego dowodzi duża liczba przykładów notowanych w tych dialektach [Kucała, 1955, s. 24], występujących aktualnie obocznie do ich wariantów z sufiksem -ny, np. tylni // tylny, dolńi // dolny, górni // górny, roczni // roczny [zob. AGP, t. 1-4, mp. 126]. Ta gwarowa cecha została utrwalona w mikrotoponimach, wśród których odnajdujemy nazwy o różnej motywacji, przede wszystkim topograficznej i kulturowej, np. Bartnia Łaka (nz. pola, pastwiska, Tarnobrzeg), Błotnia Droga (Lubelskie), Brodnie Łąki (nz. łąk, Radzyń Podlaski; nz. pola, Szydłowiec), Dalni Smug (nz. pastwiska, Siemiatycze), Dolni Ług (nz. łąki, Nowy Targ), Górnia Droga (nz. kamieniołomów, Kielce, Jędrzejów), Jezierznia (nz. łąki, Kościerzyna), Leśnia Droga (nz. drogi, Nowy Targ), Łaźnia Górka (nz. pastwiska, Mielec), Łączni Dót (od tąk; nz. zabudowan, Wejherowo), Podgórnie Pola (nz. pól, Kielce), Popławnia Droga (Lubelskie), Łąki Potocznie (nz. łąk, Jasło), Tartaczni Dół (Lubelskie), obok ich wariantów z sufiksem -ny, np. Bartna Biel (nz. bagna, łąki, Augustów), Błotna (nz. strugi, Kościerzyna), Brodna, -ej (nz. pola, Węgrów), Dalny Dót (nz. pola, Tarnobrzeg, Miechów; nz. wzniesienia, Olsztyn, Częstochowa, Racibórz), Dolny Las (nz. lasu, Ustrzyki Dolne, Brzesko), Górna Droga (nz. drogi, Gostynin, Siemiatycze, Zamość, Lubartów, Opatów, Brzeziny, Łęczyca), Jezierna, -ej (nz. góry, Trzcianka; nz. krzaków, Siemiatycze), Leśny Potok (nz. rowu, Poznań), Łąki Leśne (nz. łąk, Rypin), Łaźna Łąka (nz. łąki, Tarnów), Łączna (od łąka; nz. drogi, Wolsztyn), Popławny Dół (Lubelskie), Łąki Potoczne (nz. łąki, Jasło), Tartaczny Dót (nz. wąwozu, Opole Lubelskie).

W gwarach polskich odnajdujemy, notowane także przez źródła historyczne [zob. Karaś, 1959, s. 127-128; Kleszczowa, 2003, s. 35], przymiotniki z formantem -ny, które należy traktować jako derywaty synonimiczne wobec ich podstaw adiektywnych. Do wtórnej sufiksacji doszło np. w takich apelatywnych przymiotnikach gwarowych, jak: białny 'biały', grubny 'gruby', łakomny 'łakomy', ozimni i ozimny 'ozimy' [DejS], dtużny 'długi' [SGP], malny 'mały' [SGPIndeks], chyżny, krzywny, latosiny 'tegoroczny', pus(t)ny 'pusty', świętny (od święty 'poświęcony'), uroczny, złotny [Karaś, 1959, s. 111-118], szczerny [MAGP, mp. 232], a także blaszanny, kartoflanny, skórzanny [Karaś, 1959, s. 123-125], fachowny, prawdziwny [Chludzińska, 1956, s. 25], które występują w gwarach obok tożsamych znaczeniowo podstawowych konstrukcji bezsufiksalnych lub posiadających inny formant. Przyczyn ich ustalenia należy doszukiwać się w wyjątkowej produktywności formantu -ny, jego żywotności w polszczyźnie - od 
najdawniejszych czasów po współczesność [zob. Kleszczowa, 2003, s. 35, 161; GWJP, s. 494]. Jako znamienny wykładnik derywatów przymiotnikowych, został wprowadzony do istniejących już form, by wzmocnić ich adiektywny charakter [por. Karaś, 1959, s. 132].

Analiza omawianych nazw terenowych utworzonych od tego typu przymiotników nie tylko potwierdza występowanie w gwarach niektórych z przytoczonych formacji, np. Piachy Bialne (nz. cz. pustyni, Olkusz), Pustny Ugór (nz. pastwiska, Tarnobrzeg), Pustna Droga (nz. pola, Tarnobrzeg), Dtużne Bagienko (nz. pola, łąki, Suwałki), Krzywna, -ej (nz. drogi, Wyszogród - nz. historyczna), Malne, - ego (od maty; nz. pastwiska, Leżajsk), ale - co bardziej interesujące - uzupełnia naszą wiedzę o nowe ich przykłady, np. Kosna, -y (<-ej) (od kosy 'ukośny'; nz. pól, Bełchatów), Księżna Góra, -ej (od księży 'należący do księdza'; nz. wzgórza, Augustów), Księżna Łąka (nz. łąki, Konin), Jezioro Księżne (nz. jeziora, Czarnków).

Ilustrację podobnych zjawisk, z udziałem wtórnie wykorzystanego, pustego semantycznie formantu - ny, odnajdujemy także w mikrotoponimach utworzonych od przymiotników z formantem -any, np. Bukowianna, -ej (nz. lasu, Mielec), Marchwianna Droga, -ej (nz. drogi, Chełmo), Mszanne, -ego (nz. pola, Łosice), Różanna, -ej (<-ej) (Opoczno), Trzcianna, -ej (nz. łąki, Włoszczowa; nz. pól, łąk, Łódź), Trzcianne, -ego (nz. łąk, Włocławek; nz. pola, Kutno; nz. cz. lasu, Brzeziny; nz. pola, Łask), Ziemia Proboszanna, -ej (nz. pola, Inowrocław), Glinianna Góra (nz. wzgórza, Kościerzyna), Stawianne, -ego (nz. łąk, bagien, Świecie), Stawczanna, -ej (nz. pola, Gorlice) Zakarczmianne, -ego (nz. pola, Parczew) oraz -owy: Olszowny Lug (nz. pastwiska, Tarnobrzeg), Pniówne, -ego (nz. łąki, Parczew).

Ich lokalizacja geograficzna potwierdza w zasadzie ustalenia Mieczysława Karasia, który na podstawie materiału gwarowego stwierdził, że przymiotniki apelatywne typu np. białny, siwny, drewnianny, glinianny, rżanny, szklanny występują na Śląsku, w Wielkopolsce, na Kujawach, Pomorzu z Kaszubami, Mazowszu, w Łęczycko-Sieradzkiem, Łowickiem oraz w płn. Małopolsce [Karaś, 1959, s. 125; zob. AJK, mp. 414, 415; MAGP, mp. 154, 537, 539]. Podobnie przymiotniki trachtowny 'traktowy', deszczowny 'deszczowy' zostały zanotowane na obszarze Małopolski i Śląska [DejS, MAGP, mp. 573].

$\mathrm{Na}$ uwagę zasługują także nazwy terenowe, które przechowują dawne, archaiczne struktury przymiotnikowe $\mathrm{z}$ formantem -ski, pełniące $\mathrm{w}$ staropolszczyźnie przede wszystkim funkcję lokatywną, posesywną lub charakterystyczną [Kleszczowa, 2003, s. 24]. Utworzone zostały od nazw miejsc, pospolitych nazw osób i postaci nadprzyrodzonych, nazw instytucji, zwierząt oraz właściwości 
fizjograficznych terenu. Wchodzą one w relacje synonimiczne z nazwami zawierającymi przymiotniki o innych wykładnikach formalnych, tworząc szeregi dwu- i trójelementowe:

-ski : -owy : -ny, np. Dolska Góra (nz. góry, lasu, Jasło) - Dołowa, -ej (nz. pola, Śrem, Maków Mazowiecki) - Dolna Łąka (nz. pola, Chrzanów), Dolna Droga (nz. wąwozu, Jędrzejów; nz. drogi, Brzeziny; nz. pola, Busko); Polska Droga 'polna' (nz. drogi, Gościszewo), Za Polska Droga (nz. pola, Nowy Targ) - Polowa Droga (nz. drogi, Śrem) - Polny Sad (nz. pola, Kazimierza Wielka);

-ski : -i : -owy, np. Popski Las (nz. lasu, Chełm) - Popi Staw (nz. stawu, Tychy) - Popowy Ług (nz. pola, bagna, Hajnówka);

-ski : -i, np. Krecka Góra (od kret; nz. zalesionej góry, Lubliniec) - Krecia Góra (nz. góry, Chojnice); Psiackie Góry (nz. lasu, Kolbuszowa) - Psie Doły, Psie Górki (Lubelskie);

-ski : -ny, np. Folwarski Las (nz. lasu, Ostrów Wielkopolski) - Folwarczny, - ego (nz. lasu, Siedlce, Maków Mazowiecki; nz. stawu, Bielsko-Biała); Gmiński Las (nz. lasu, Częstochowa), Gmińska Łąka (nz. łąki, Suwałki), Gmińska Góra (nz. góry, Poznań) - Gminny Las (nz. lasu, Środa, Mogilno, Inowrocław, Szubin, Tuchola, Tarnobrzeg, Mielec, Chrzanów, Żywiec), Gminna Glinica (nz. stawu, Mogilno), Gminna Góra (nz. wzgórza, piaskownicy, Wąbrzeźno); Piekielskie Łąki (nz. łąk, Rypin) - Piekielny Ług (nz. lasu, Kraśnik), Piekielny Smug (nz. łąk, krzaków, Staszów), Piekielny Rów (nz. rowu, Wejherowo);

-ski : -any, np. Hrabski Las (nz. lasu, Szubin), Hrabska Góra (nz. góry, Kościerzyna) - Hrabiana Góra (nz. góry, nieużytku, Proszowice).

Zarówno zakres semantyczny podstaw, od których utworzono zaprezentowane przymiotniki, będące składnikiem nazw terenowych, jak i zjawisko rywalizacji formantów je tworzących, zbieżne są ze stanem zaobserwowanym w staropolszczyźnie [zob. Kleszczowa, 2003, s. 24-25] oraz danymi gwarowymi. Formacje apelatywne, np. polski, polowy 'polny', folwarski, hrabski, gmiński, piekielski, ale również kurski 'kurzy', krówski 'krowi', bociański 'bociani', notowane są w polskich źródłach gwarowych [zob. np. DejS, SGP, SGPIndeks], co potwierdza wyjątkową aktywność formantu -ski w dawnej polszczyźnie i w jej odmianach regionalnych. Analiza dubletów przymiotnikowych nazw własnych, utworzonych od tych samych podstaw za pomocą różnych genetycznie formantów, wspiera formułowanie wniosków na temat rozwoju systemu słowotwórczego przymiotników pospolitych funkcjonujących w gwarach, który w dużej mierze jest odbiciem zmian zachodzących w polszczyźnie ogólnej. 
Zasób polskich mikrotoponimów, tworzonych przez mieszkańców wsi, mówiących na co dzień gwara, odzwierciedla nie tylko tendencje nazewnicze, ale także utrwalone w nazwach właściwości morfologiczne, charakterystyczne dla dialektów polskich. Zaproponowany sposób wykorzystania danych onomastycznych do badań słowotwórstwa gwarowego, dokonany na przykładzie terenowych nazw przymiotnikowych, pokazuje, że mogą one:

1) być pomocne w geografii lingwistycznej poszczególnych typów słowotwórczych wyrazów pospolitych, weryfikować naszą dotychczasową wiedzę na temat ich zasięgów;

2) uzupełnić zasób formacji słowotwórczych o leksemy dotąd nienotowane w gwarach, charakteryzujące się cechami morfologicznymi, znanymi z polszczyzny historycznej;

3) dostarczyć nowych przykładów, potwierdzających występowanie w polszczyźnie regionalnej zjawiska słowotwórczej wariantywności oraz tautologii derywatów;

4) poprzez analizę, pochodzących z różnych cezur chronologicznych, nazw własnych ilustrować zjawiska językowe w zakresie kontynuacji lub innowacyjności w obrębie poszczególnych kategorii i typów słowotwórczych.

\section{ROZWIĄZANIA SKRÓTÓW}

AGP - Dejna Karol, 1998, Atlas gwar polskich, t. 1., Małopolska, Warszawa; Dejna Karol, Gala Sławomir, Zdaniukiewicz Alojzy, CZYŻEwski Feliks, 2000, t. 2. Mazowsze, Warszawa; Desna Karol, Gala Sławomir, 2001, t. 3, Śląsk, Warszawa; Dejna Karol, 2002, t. 4, Wielkopolska, Kaszuby, Warszawa.

AJK - StIEBER Zdzisław, PopowsKa-TABOrsKa Hanna, red., 1964-1978, Atlas językowy kaszubszczyzny i dialektów sąsiednich, t. 1-15, Wrocław.

DejS - Dejna Karol, 1974-1985, Słownictwo ludowe z terenu województw kieleckiego i łódzkiego, „Rozprawy Komisji Językowej Łódzkiego Towarzystwa Naukowego", (A-B) 1974, 20, s. 189-277; (C-D), 1975, 21, s. 135-290; DeJnA Karol, 1976-1985, Słownictwo ludowe z terenu byłych województw kieleckiego i łódzkiego, „Rozprawy Komisji Językowej Łódzkiego Towarzystwa Naukowego" (E-J) 1976, 22, s. 135-268; (K), 1977, 23, s. 147-290; (L-M) 1978, 24, s. 149-274; (N-Ó), 1979, 25, s. 123-276; (Pa-Por) 1980, 26, s. 117-257; (Pos-R), 
1981, 27, s. 129-281; (Sa-Sy) 1982, 28, s. 119-261; (Sz-U) 1983, 29, s. 83-233; (W), 1984, 30, s. 91-213; (Z-Ż), 1985, 31, s. $143-265$.

GWJP - Grzegorczykowa Renata, LASkowski Roman, WróBel Henryk, red., 1998, Gramatyka współczesnego języka polskiego. Morfologia, Warszawa.

MAGP - Mały atlas gwar polskich, t. I-XIII, red. K. Nitsch (t. I-II), M. Karaś (t. III-XIII), Wrocław 1957-1970.

SGP - Słownik gwar polskich, 1979-2013, t. 1-8, Kraków.

SGPIndeks - Indeks alfabetyczny wyrazów z kartoteki Słownika gwar polskich, 1999, t. 1-2, red. J. Reichan, Kraków.

\section{Skróty konwencjonalne}

cz. - część.

nz. - nazwa.

\section{BIBLIOGRAFIA}

ChludziŃsKa Jadwiga, 1956, Przymiotniki w gwarach Warmii i Mazur. (Uwagi słowotwórczo-semantyczne), „Poradnik Językowy”, s. 21-27

Cieślikowa Aleksandra, 2003, Leksykografia onomastyczna a leksykografia gwarowa, w: Gwary dziś. 2. Regionalne słowniki i atlasy gwarowe, red. J. Sierociuk, Poznań, s. 21-27.

Dejna Karol, 1993, Dialekty polskie, wyd. 2, Wrocław - Warszawa - Kraków.

Dejna Karol, 1994, Atlas polskich innowacji dialektalnych, wyd. 2, Łódź.

Gala Sławomir, 1986, Antroponimia a dialektologia - zależności metodyczne, „Acta Universitatis Lodziensis. Folia Linguistica”, 12, s. 25-36.

GaLA Sławomir, 2001, Antroponimia ludowa w badaniach nad słowotwórstwem gwarowym, w: W świecie słów i znaczeń. Księga pamiątkowa dedykowana Profesorowi Bogusławowi Krei, red. J. Maćkiewicz, E. Rogowska, Gdańsk, s. $103-107$.

Gala Sławomir, 2003, Słowotwórstwo onomastyczne i słowotwórstwo gwarowe, w: Metodologia badań onomastycznych, pod red. M. Biolik, Olsztyn, s. 58-62. GAJDA Stanisław, 1987, Przymiotnikowe sufiksy -at- i -ast- w polskiej toponimii, „Zeszyty Naukowe WSP w Opolu. Językoznawstwo X”, s. 21-34.

JAROS Irena, 2001, Gwary opoczyńskie na tle językowego pogranicza Małopolski i Mazowsza, „Acta Universitatis Lodziensis. Folia Linguistica”, 40, Łódź. 
KARAŚ Mieczysław, 1959, O strukturach słowotwórczych typu bialny, którny w języku polskim, „Biuletyn Polskiego Towarzystwa Językoznawczego”, XVIII, s. 113-135.

KLeszczowa Krystyna, 2003, Staropolskie derywaty przymiotnikowe i ich perspektywiczna ewolucja, Katowice.

KuCAŁA Marian, 1955, Znaczenie i zasięg przymiotników na -ni (przedni, letni), „Język Polski”, 1, s. 8-26.

MrózeK Robert, 1998, Nazwy terenowe, w: Polskie nazwy własne. Encyklopedia, red. E. Rzetelska-Feleszko, Warszawa, s. 231-257.

MRÓZEK Robert, 2014, Zadania współczesnej toponomastyki w świetle wewnętrznych zróżnicowań i perspektyw badawczych, w: Makrotoponima i mikrotoponimia. Problematyka wstępna, red. A. Gałkowski, R. Gliwa, Łódź, s. 26-33.

Pelcowa Halina, 2007, Nazwy terenowe w interpretacji dialektologicznej, w: Polszczyzna Mazowsza i Podlasia, t. XI: Nazwy terenowe i nazewnictwo miejskie Mazowsza i Podlasia, red. H. Sędziak, M. Dajnowicz, Łomża, s. 11-17.

Rospond Stanisław, 1986, Dialektologia a toponimia, „Acta Universitatis Lodziensis. Folia Liguistica", 12, s. 55-67.

Rzetelska-FeleszKo Ewa, 1986, Metody dialektologiczne w onomastyce, „Acta Universitatis Lodziensis. Folia Linguistica", 12, Łódź, s. 69-78.

SATKIEwICZ Halina, 1987, Zagadnienia poprawności słowotwórczo-semantycznej, w: Kultura języka polskiego, Zagadnienia poprawności leksykalnej (Słownictwo rodzime), Warszawa, s. 229-439.

TASZYCKI Witold, 1963, Stosunek onomastyki do innych nauk humanistycznych, „Onomastica”, VIII, s. 1-19.

ŚMIECH Witold, 1983, Stosunek polskich nazw terenowych do wyrazów pospolitych, w: Geografia nazewnicza, red. K. Rymut, Wrocław, s. 37-51.

Śmiech Witold, 1996, Przymiotnikowe nazwy terenowe Polski, Łódź.

Winkler-LeszCZyŃsKa Irena, 1964, Sufiksy przymiotnikowe -ity, -isty, -aty, -asty w języku polskim na tle ogólnosłowiańskim, Wrocław - Warszawa - Kraków

ZARĘBA Alfred, 1968, Dialektologia a onomastyka, „Onomastica”, XIII, s. 7-25. 